\title{
Téoros
}

Revue de recherche en tourisme

\section{Strategy for Selecting Sustainable Tourism Indicators for the Gaspésie and Îles de la Madeleine Regions}

\section{Juste Rajaonson et Georges A. Tanguay}

Numéro hors-série, 2012

Innovations en tourisme durable

Innovations in Sustainable Tourism

URI : https://id.erudit.org/iderudit/1036567ar

DOI : https://doi.org/10.7202/1036567ar

Aller au sommaire du numéro

Éditeur(s)

Université du Québec à Montréal

ISSN

0712-8657 (imprimé)

1923-2705 (numérique)

Découvrir la revue

Citer cet article

Rajaonson, J. \& Tanguay, G. A. (2012). Strategy for Selecting Sustainable Tourism Indicators for the Gaspésie and Îles de la Madeleine Regions. Téoros, 77-84. https://doi.org/10.7202/1036567ar
Résumé de l'article

This article describes the creation of a grid of sustainable tourism indicators, specifically the strategy adopted by the Gaspésie and Îles de la Madeleine regions of Québec. First, a list of indicators recognized by experts, which systematically cover the dimensions of sustainable tourism, was compiled. In the second step, the indicators were coordinated with the sustainable tourism policy framework of each region, to operationalize the indicators while preserving their validity. This two-step strategy led to identification of a list of recognized and measurable sustainable tourism indicators consistent with the tourism policy of each region. This approach thus minimizes the risks of instrumentalization of the concept of sustainable tourism, and guarantees the validity of the assessment and follow-up approaches in this area. 


\title{
Strategy for selecting sustainable tourism indicators for the Gaspésie and Îles de la Madeleine regions
}

\author{
Juste RAJAONSON \\ Doctoral student \\ Departement of Urban and Tourism Studies \\ Université du Québec à Montréal \\ rajaonson.juste@courrier.uqam.ca \\ Georges A. TANGUAY, Ph.D. \\ Professor \\ Departement of Urban and Tourism Studies \\ Université du Québec à Montréal \\ tanguay.georges@uqam.ca
}

\begin{abstract}
This article describes the creation of a grid of sustainable tourism indicators, specifically the strategy adopted by the Gaspésie and Îles de la Madeleine regions of Québec. First, a list of indicators recognized by experts, which systematically cover the dimensions of sustainable tourism, was compiled. In the second step, the indicators were coordinated with the sustainable tourism policy framework of each region, to operationalize the indicators while preserving their validity. This two-step strategy led to identification of a list of recognized and measurable sustainable tourism indicators consistent with the tourism policy of each region. This approach thus minimizes the risks of instrumentalization of the concept of sustainable tourism, and guarantees the validity of the assessment and follow-up approaches in this area.
\end{abstract}

Keywords : indicators, sustainability, assessment, methology, partnership.

Policy implementation usually entails the use of follow-up and assessment tools such as indicators. These tools are considered essential means of accounting for unexpected outcomes and measuring the consequences of action or inaction (Boulanger, 2004; Bell and Morse, 2008). In sustainable tourism, their main objective is to offer a global assessment of the link between nature and society, to help decision makers evaluate actions to undertake or not, and thus orient tourism and related activities toward sustainable development (Hunter, 1997).

Developing a set of sustainability indicators is nonetheless a difficult task, because subjectivity is inevitably introduced at each step, from the selection of indicators to their interpretation (Wong, 2006). Several authors have proposed approaches and conceptual frameworks to guide the process of formulating indicators, particularly in the area of environmental management (Bell and Morse, 2008). These initiatives fall into two categories: some researchers see sustainability as a complex concept necessitating the development of sophisticated measurement tools, while others view it as an objective to be achieved through political concensus resulting from discussion among the stakeholders (Rametsteiner et al., 2011). In the first case, the result is a grid of indicators that, although pertinent, may be perceived as overly complex by decision makers (Shield et al., 2002). In the second case, the indicator grid risks evaluating dimensions considered important largely by the stakeholders, and thus becoming a territorial marketing tool (Rajaonson and Tanguay, 2010).

These findings justify the development of an alternative strategy to compile a more concise list of indicators that both experts and stakeholders in tourist destination will recognize. In this paper we present an example of the use of such a strategy, like the one adopted in the Québec regions of Gaspésie and Îles de la Madeleine, which formulated a grid of indicators as part of an assessment of sustainable tourism. To explain this regional experience, we first briefly review the types of approaches generally adopted when formulating a grid of sustainable tourism indicators. We then describe the context that led the two regions to choose an intermediate approach to creating such a grid, and outline the subsequent steps involved in selecting a short list of indicators and adapting them to the context of each region. Lastly, we identify the main advantages of their strategy, emphasizing the integration of scientific expertise and local experience. 


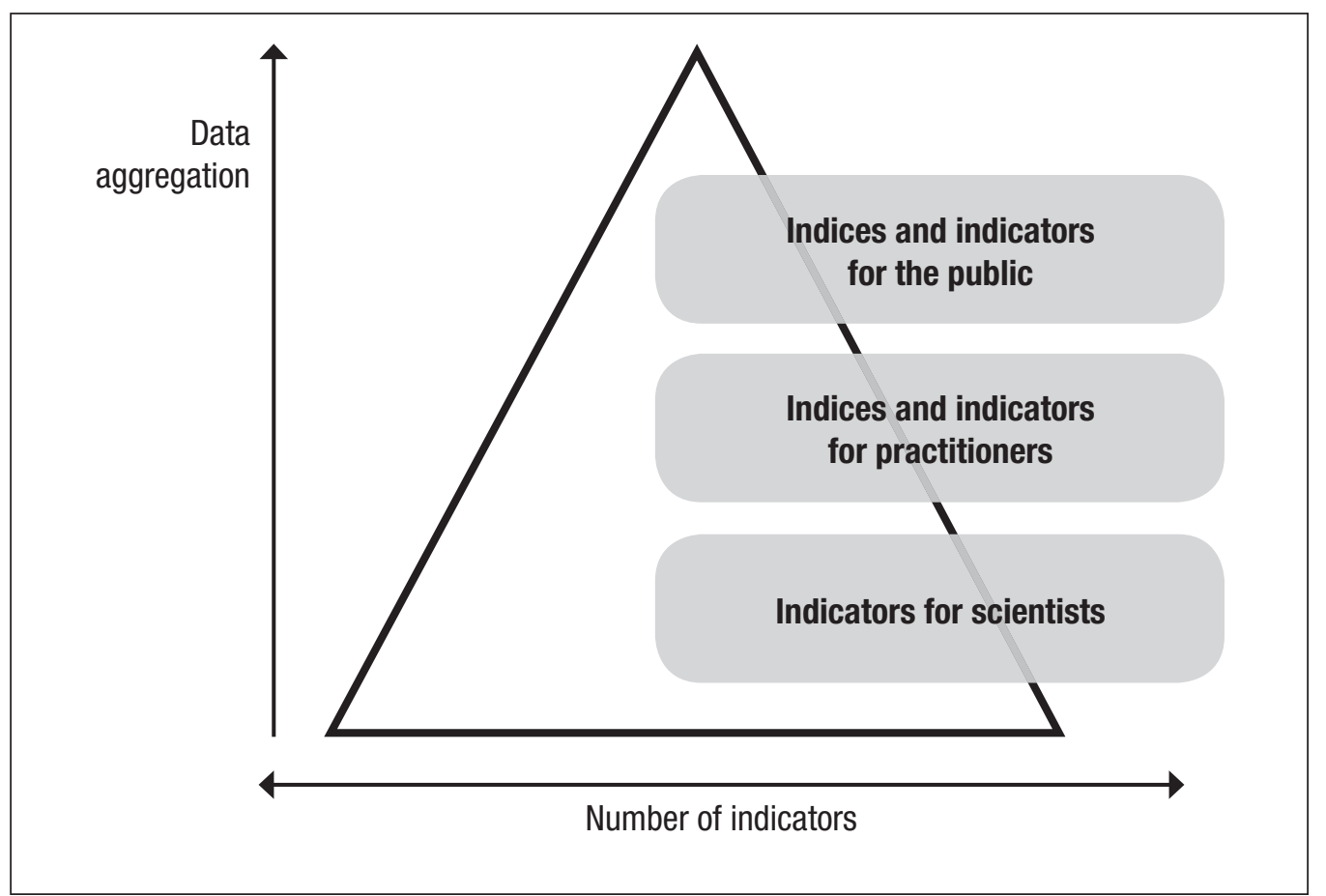

Figure 1 : Number of indicators and target audience (source : adapted from Shield et al. (2002)).

\section{Indicators development}

There are two main approaches to the formulation of sustainable tourism indicators (STI) depending on the objectives of the exercise (Rametsteiner et al., 2011). First, the scientific approach is generally intended to amass a large quantity of information to maximize precision (Miller, 2001; Choi and Sarakaya, 2006; Tasser et al., 2008; Niemeijer and de Groot, 2008; Hickey and Innes, 2008). Often, the result is a scientifically valid grid that is poorly received by decision makers owing to its complexity (Hunter, 1997).

In the second approach, favored by decision makers and practitioners, the data originally available are condensed in the form of synthetic indicators to support political decisions and are simplified for public dissemination (see Figure 1). This approach rests on particular needs and/or political objectives, which justify the creation of an STI grid (Stabler, 1997; Butler, 1999; Gahin et al., 2003; Reed et al., 2006). The grid thus results from consensus among several actors, rather than from a search for a neutral, credible and reproducible system (Rametsteiner et al., 2011).

Recently, several authors have attempted to integrate the two approaches by considering their weaknesses and seeking the best compromise (Bell and Morse, 2008; Holman, 2009; Rametsteiner et al., 2009; Rajaonson and Tanguay, 2010). These studies build on the findings that the production of indicators based on a purely scientific process tends to ignore or underestimate the importance of the political dimension (Rametsteiner et al., 2011). This would explain why the resulting indicators are not viewed as legitimate by decision makers and civil society. In contrast, the approach based on a quest for political census creates a bias in the development of indicators and introduces subjectivity decried by scientists. The content and priorities of the indicators thus reflect the affiliations of the actors involved in the process (Hunter, 1997). In the alternative approach, the formulation of indicators becomes a process of knowledge production with a scientific foundation, combined with the setting of a political and operational standard (Rametsteiner et al., 2011) that facilitates the recognition and scientific and social legitimacy of the indicators.

Beyond the importance of balancing science and policy, a real reference framework for the formulation of STI is lacking. This has led to an explosion of forms of STI grids, legitimized by the particular characteristics of each territory. Such grids might be overly specific, or ignore some or all of the fundamental principles of sustainable tourism. While recognizing that each region needs its own indicators, Mascarenhas et al. (2010) underline the need to converge toward a common structure, to establish coherence in the assessment of sustainable tourism development. This requirement averts the instrumentalization of indicators in territorial marketing (European Environment Agency, 2001). A large body of literature proposes the use of common and flexible assessment grids, and underscores the value of striving for coherence in sustainable development assessment methods (Mitchel, 1996; Holman, 2009; Mascarenhas et al., 2010). Nonetheless, the use and formulation of such grids is problematic, particularly regarding the accessibility of data.

A STI grid that is compatible with several destinations faces constraints of observation and measurement. Several inevitable compromises often limit the analytical efficiency of the indicators and undermine their objectivity. Notably, one must consider users' demand for concise information, 
the desire to obtain results based on a coherent methodological approach, and the data supply (Holman, 2009). In a calculation exercise, this compromise is often translated by the use of less explicit indicators for which calculation data are available on the appropriate analytical scale. Poverty is one example. It is commonly measured using one or several indicators related to income, expenses and household dwelling type, because such statistical data are easily accessible. However, in addition to the material dimension, poverty is characterized by social and cultural dimensions (e.g. exclusion, education) for which there are several other equally pertinent indicators whose measurement sometimes requires more complex calculations, surveys or adjustments (Boulanger, 2004). Given the constraints inherent in the formulation of indicators, it will be shown below that the Gaspésie and Îles de la Madeleine regions had to make several compromises to arrive at the final list of indicators. For one, it was crucial to take into account their respective sustainable tourism policy frameworks, the broad outlines of which are presented in the next section.

\section{Sustainable tourism policy framework in Gaspésie and îles de la Madeleine}

The Gaspésie peninsula and the Îles de la Madeleine archipelago form one of the 17 administrative regions of the province of Québec. Differentiated by their physical and human geography, the two regions offer different tourism products and do not share the same development issues. This reality is illustrated in Table 1.

To guarantee the sustainability of their tourism sector and maintain competitive attractiveness, the two regions took steps to adopt a tourism policy that abides by the principles of sustainable development. These policies were formulated based on a participatory approach involving a series of consultations and discussions among the authorities, the local population and tourism operators. The objective was to formulate a consensual and realistic vision of tourism development, and set common objectives for all the stakeholders.

\section{Gaspésie}

National Geographic Traveler named the Gaspésie region one of the 20 destinations to visit in 2011 (National Geographic Traveler, 2010). In a short explanatory text, National Geographic justified its choice by the beauty of a landscape sculpted by the wind and sea, the presence of the Appalachians, 25 of the main summits in Québec, four national parks and wildlife reserves, and a wide range of winter activities. The previous year, the same organization ranked Gaspésie third in the list of top global tourist destinations based on six criteria: environmental quality, social and cultural integrity, quality of tourism management, condition of buildings and archaeological sites, aesthetics and future potential of the destination (Figure 1). This evaluation was done by a panel of 437 tourism experts (National Geographic Traveler, 2010).

In 2010, the Conférence régionale des élus de la GaspésieÎles-de-la-Madeleine (CRÉGÎM), the administrative entity
Table 1: Characteristics of Gaspésie and Îles de la Madeleine

\begin{tabular}{l|l}
\hline Gaspésie & Îles de la Madeleine \\
\hline $3000 \mathrm{~km}$ of coastline & $300 \mathrm{~km}$ of coastline \\
\hline 100,000 inhabitants & 14,232 inhabitants \\
\hline $\begin{array}{l}3^{\text {rd }} \text { best destination in the world, for } \\
\text { sustainable development (NG, 2009) } \\
\text { One of the top 20 global destinations } \\
\text { to visit (NG, 2011) }\end{array}$ & $\begin{array}{l}\text { Dream destination according to } \\
\text { surveys on Quebec tourism regions } \\
\text { conducted in Québec (Ministère du } \\
\text { Tourisme du Québec, 2010) }\end{array}$ \\
\hline $\begin{array}{l}\text { Natural landscapes, diverse cultural } \\
\text { heritage, many festivals }\end{array}$ & $\begin{array}{l}\text { Natural landscapes, cruises, bird and } \\
\text { aquatic wildlife observation }\end{array}$ \\
\hline \multicolumn{2}{l}{ Source : Authors' compilation. }
\end{tabular}

grouping the two tourist regions, launched a Policy framework for sustainable tourism in the Gaspésie (CRÉGÎM, 2010) following a consultation of tourism operators and the public on the future of tourism in the region. This event brought together over 300 people, and identified assets, weaknesses, constraints and opportunities in the Gaspésie tourism sector. A follow-up committee coordinated by a project manager was subsequently formed. For eight months, this committee held several meetings with various stakeholders, culminating in the adoption and unveiling of the Policy framework for sustainable tourism in the Gaspésie (PFSTG) in November 2010. Five guiding principles were identified, together with associated objectives (see Table 2). These principles will guide the choice of sustainable tourism indicators. Beyond the application of general criteria allowing the selection of a series of optimal indicators, the indicators must be operational and coherent with the PFSTG.

\section{îles de la Madeleine}

The Îles de la Madeleine archipelago is a sought after destination by Quebecers. They regularly choose the archipelago as a dream destination in surveys about tourist regions in the province of Québec (Municipalité des Îles-de-laMadeleine, 2006). Sustainable development is a central priority of the region, translated into numerous projects, particularly as part of the regional action plan supported by the Ministère du développement économique, de l'innovation et de l'exportation du Québec (Municipalité des Îles-de-la-Madeleine, 2006).

In 2006, the Îles de la Madeleine adopted the Policy framework for sustainable tourism in the Îles de la Madeleine (PFSTIM) after two years of consultation (Municipalité des Îles-de-la-Madeleine, 2006). This consultation was necessitated by strong variations in traffic resulting from an increase in the capacity of maritime service from Prince Edward Island, and the introduction of ferry service from Montréal. Approved by all the socioeconomic partners including the CRÉGÎM, the Îles-de-la-Madeleine RCM and the Regional Tourism Association of the Îles de la Madeleine, a follow-up committee was formed, including a representative of each of these organizations, to supervise 
Table 2: Guiding principles and objectives of the PFSTG

\begin{tabular}{|c|c|}
\hline Guiding principle 1 & Safeguarding and developing Gaspesian culture \\
\hline Objective 1 & Develop original production of the territory, for terroir products (agri-food, agri-forestry, seafood) and artistic products. \\
\hline Objective 2 & Make the history and heritage of the region more accessible to visitors. \\
\hline Objective 3 & $\begin{array}{l}\text { Preserve and develop the region's docks and lighthouses, which are important witnesses of our history } \\
\text { and maritime identity. }\end{array}$ \\
\hline Objective 4 & Ensure that all regional tourism products reflect the population of the territory. \\
\hline Guiding principle 2 & Ensure that all regional tourism products reflect the population of the territory \\
\hline Objective 1 & $\begin{array}{l}\text { Adopt and implement, on the regional and local scales, measures to protect and develop the landscape } \\
\text { and built heritage. }\end{array}$ \\
\hline Guiding principle 3 & Promotion of eco-responsibility \\
\hline Objective 1 & Identify and implement measures to make the Gaspésie destination more eco-responsible. \\
\hline Guiding principle 4 & Participating governance and endogenous development \\
\hline Objective 1 & $\begin{array}{l}\text { Facilitate the ownership of attractions, events and tourism infrastructures by the community, and favour } \\
\text { their co-development. }\end{array}$ \\
\hline Objective 2 & Maximize the local benefits of tourism. \\
\hline Objective 3 & $\begin{array}{l}\text { Ensure the complementarity of activities, events and attractions in tourist offerings by encouraging concerted actions } \\
\text { among the various actors concerned. }\end{array}$ \\
\hline Guiding principle 5 & Sustainability of tourism \\
\hline Objective 1 & Improve the reception of the tourism clientele. \\
\hline Objective 2 & Optimally use our distinctive resources, strongly associated with the maritime and mountainous nature of the region. \\
\hline Objective 3 & Strive to improve tourist traffic throughout the year and increase the duration of visitors' stays. \\
\hline Objective 4 & Facilitate access to the Gaspésie. \\
\hline Objective 5 & Develop the Gaspésie tourism offering. \\
\hline
\end{tabular}

the implementation of an annual action plan that prioritized the use of sustainable tourism indicators. As Table 3 illustrates, the PFSTIM rests on four fundamentals that are divided into several objectives.

To summarize, the two partner regions consider the implementation of STI a priority, to ensure effective followup of action plans arising from their respective policy frameworks. They have thus chosen a strategy intended to select pertinent indicators applicable to their specific context. The next section describes the innovative experience of the Gaspésie and Îles de la Madeleine, where scientific expertise was coupled with indicators aligned with their needs.

\section{Strategy for selection \\ of sustainable tourism indicators}

The first choice the two regions made was to solicit external expertise, for two main reasons. The first was to avert the lack of consensus and conflicts of interest that could result from a process that mainly involves local players. The second was to choose from among recognized indicators whose pertinence has been demonstrated by experts and in other destinations.
Therefore, the strategy used by the Gaspésie and Îles de la Madeleine regions consists in compiling an exhaustive inventory of indicators recommended by experts. The first step was to create a database of sustainable tourism indicators. These indicators were taken from the World Tourism Organization manual Indicators of Sustainable Development for Tourism Destinations: A Guidebook (World Tourism Organization [WTO], 2004). Initially, 768 indicators were noted. Several were eliminated because of redundancy. The indicators retained addressed factors that reflected dynamics similar to those of the Gaspésie and the Îles de la Madeleine regions. For example, indicators related to hygiene and access to drinking water, which are generally used for destinations in developing countries, were not retained. The resulting database contained 507 indicators.

The indicator selection strategy used to obtain a list of pertinent and operational indicators for both tourism regions was based on that of Tanguay et al. (2009). Further, two series of criteria were applied to the 507 indicators gathered: a series of general criteria, followed by a series of criteria designed to adapt the indicator grid to the contexts of the two regions. 
Table 3: Fundamentals and objectives of the PFSTIM

\begin{tabular}{|c|c|}
\hline Fundamental 1 & $\begin{array}{l}\text { Tourism development must, through its economic, social and cultural impact, benefit } \\
\text { the community and contribute to increasing the quality of life of the Madelinots. }\end{array}$ \\
\hline Objective 1 & Optimize the sharing of economic benefits among a large proportion of the population \\
\hline Objective 2 & Reconcile tourism development with maintenance and improvement in residents' quality of life. \\
\hline Fundamental 2 & $\begin{array}{l}\text { Tourism development must contribute to enhancing and preserving biodiversity and } \\
\text { the specific characteristics of our physical environment }\end{array}$ \\
\hline Objective 1 & Reinforce the territory management framework. \\
\hline Objective 2 & $\begin{array}{l}\text { Ensure conservation of non-buildable natural space, accessible to all, along with certain sites and landscapes that } \\
\text { represent our collective heritage. }\end{array}$ \\
\hline Objective 3 & $\begin{array}{l}\text { Control the implementation and deployment of infrastructures, facilities and activities on the territory with respect } \\
\text { for natural heritage, }\end{array}$ \\
\hline Objective 4 & Implement sustainable development strategies applicable daily to the tourism offering \\
\hline Fundamental 3 & $\begin{array}{l}\text { Tourism development must represent an opportunity to enhance and preserve the identity, local } \\
\text { culture, maritime and insular way of life, namely the Madelinot heritage. }\end{array}$ \\
\hline Objective 1 & Maintain, enhance and promote the culture and maritime and insular heritage, namely the Madelinot identity. \\
\hline Objective 2 & Highlight the social and cultural benefits of tourism and benefits to the population. \\
\hline Objective 3 & Favour relations between visitors, resort vacationers and residents. \\
\hline Objective 4 & Promote the development of authentic, high quality products, attractions, activities and events \\
\hline Fundamental 4 & $\begin{array}{l}\text { Tourism development must complement other economic activities, particularly those related to } \\
\text { the harvesting of ocean and land resources. }\end{array}$ \\
\hline Objective 1 & Enhance the interaction between fishing and tourism while developing fishing. \\
\hline Objective 2 & Support agriculture development initiatives. \\
\hline Objective 3 & Highlight regional products as an important component of the tourism product and develop regional cuisine. \\
\hline Objective 4 & $\begin{array}{l}\text { Sensitize tourism stakeholders and other merchants to the importance of the quality of hospitality and of the products } \\
\text { and services offered to visitors. }\end{array}$ \\
\hline
\end{tabular}

Source : Municipalité des Îles-de-la-Madeleine (2006).

\section{General criteria}

The first series consists of four general criteria intended to reduce the initial list of 507 indicators to a more synthetic grid that covers the main dimensions and sustainable development issues. The general criteria concern: i) classification of indicators according to sustainable development dimensions; ii) frequency of use of indicators according to sustainable development dimensions; iii) coverage of the WTO's main dimensions of sustainable development and iv) measurability of indicators over time. The first criterion is intended to categorize the 507 indicators according to the environmental, social and economic dimensions of sustainable development, while taking into account their intersections. The second criterion serves to identify the most frequently used indicators whose pertinence and usefulness are recognized by experts and the tourism destinations concerned. To reinforce the validity of this criterion, the list of 507 indicators was compared with 16 case studies selected for their pertinence, in which the frequency of use of the STI was analyzed. The third criterion defines a threshold from which the reduced list of indicators reproduces the coverage of the dimensions of sustainable development of the 507 initial indicators most broadly and covers the main issues of sustainable development as defined in the WTO manual on sustainable tourism indicators (see Table 4). Lastly, the fourth criterion identifies, from among the indicators retained at this step, those that vary over time, to demonstrate the evolution of the situation. If annual indicators are generally preferred, those that vary over a longer time period are also useful because they may show progress that may not be visible over a five- to ten-year period.

\section{Specific criteria}

We applied a second series of three specific criteria to adjust the reduced list of indicators to the particular context of the Gaspésie and the Îles de la Madeleine. These criteria therefore supplement the four preceding general criteria, and are intended to ensure i) the availability of data; ii) correspondence with the indicators with the PFSTG and the PFSTIM, and iii) that the authorities in both regions validate the indicators. The first criterion serves to confirm whether the data are available for the tourism regions of the Gaspésie and the Îles de la Madeleine. An indicator that has a valid base but for which data are not available for one or both regions may be replaced by a substitute indicator. This is crucial to ensure 


\section{Table 4: Sustainable development issues in tourism}

\begin{tabular}{c|l|c|l}
\hline $\mathbf{N}^{\circ}$ & Issues & $\mathbf{N}^{\circ}$ & Issues \\
\hline $\mathbf{1}$ & Natural space, flora, and fauna & $\mathbf{1 1}$ & Public participation \\
\hline $\mathbf{2}$ & Water & $\mathbf{1 2}$ & Culture \\
\hline $\mathbf{3}$ & Atmosphere & $\mathbf{1 3}$ & Accessibility \\
\hline $\mathbf{4}$ & Energy & $\mathbf{1 4}$ & Investments \\
\hline $\mathbf{5}$ & Waste & $\mathbf{1 5}$ & Promotion of ecotourism \\
\hline $\mathbf{6}$ & Landscapes and nuisances & $\mathbf{1 6}$ & Economic vitality \\
\hline $\mathbf{7}$ & Resilience and risk & $\mathbf{1 7}$ & Employment \\
\hline $\mathbf{8}$ & Security and safety & $\mathbf{1 8}$ & Marketing \\
\hline $\mathbf{9}$ & Health & $\mathbf{1 9}$ & Distinction \\
\hline $\mathbf{1 0}$ & Satisfaction & $\mathbf{2 0}$ & Traffic \\
\hline Source : Adapted from WT0 (2004). & \multicolumn{2}{|l}{} \\
\hline
\end{tabular}

that the indicators are usable. At this step, even if some subjectivity is introduced, the indicators selected are generally equivalent, when possible, or at least cover the same issues as the indicators they replace. This exercise underlines gaps in the statistical data measured at the regional scale, which would imply that the authorities should take corrective action. The second specific criterion affirms whether the indicators are consistent with the policy documents of each region. Accordingly, each indicator is reclassified according to the guidelines of the PFSTG in the case of the Gaspésie, and to the fundamentals of the PFSTIM for the Îles de la Madeleine. Lastly, because the indicators must apply to two tourism regions with distinctive characteristics, the fourth criterion rests on validation of indicators by the authorities, to ensure that they are truly useful and inclusive. It is based on this criterion that the characteristics and problems specific to each region are taken into account. The selection process is depicted in Figure 2.

Table 5: Correspondence of STI

\begin{tabular}{|c|c|c|}
\hline Indicators satisfying the general criteria & Indicators available for Gaspésie & $\begin{array}{l}\text { Indicators available } \\
\text { for Îles de la Madeleine }\end{array}$ \\
\hline Area of protected space & Area of controlled harvesting zones & Area of wetlands \\
\hline Water consumption (tourism sector) & Number of municipalities that treat wastewater & $\begin{array}{l}\text { Number of purification stations that received a grade higher } \\
\text { than } 85 \% \text { for compliance with station requirements }\end{array}$ \\
\hline Air pollution (tourism sector) & Use of public transport network (highway sector) & Use of public transport network (maritime sector) \\
\hline Energy consumption (tourism sector) & Number of actions or planned commitments carried out & Number of actions or planned commitments carried out \\
\hline Volume of waste recycled & Waste recovery rate $\mathrm{s}(\mathrm{I} \mathrm{BI})$ & Waste recovery rates (IBI) \\
\hline $\begin{array}{l}\text { Level of satisfaction of the local population with tourism } \\
\text { development }\end{array}$ & $\begin{array}{l}\text { Level of satisfaction of the local population with tourism } \\
\text { development }\end{array}$ & $\begin{array}{l}\text { Level of satisfaction of the local population with tourism } \\
\text { development }\end{array}$ \\
\hline Environmental vulnerability & Investment in developing the tourism offering & Investment in developing the tourism offering \\
\hline Ratio between tourists and local population at cultural events & Number of visitors to museums & Number of visitors to museums \\
\hline Quality of bodies of water (lakes, rivers sea) & Number of public beaches & Number of public beaches \\
\hline Level of tourist satisfaction & General evaluation index of reception service by tourists & Level of tourist satisfaction \\
\hline $\begin{array}{l}\text { Number of municipalities that have a committee, corporation } \\
\text { or tourism development office }\end{array}$ & Investment by regional tourism authorities to promote tourism & Investment by regional tourism authorities to promote tourism \\
\hline Level of maintenance of heritage sites & Québec public administration spending on culture & Québec public administration spending on culture \\
\hline $\begin{array}{l}\text { Level of use of existing transportation modes to reach } \\
\text { destination }\end{array}$ & $\begin{array}{l}\text { Investment in maintenance and development of the transpor- } \\
\text { tation network to the destination (highway sector) }\end{array}$ & $\begin{array}{l}\text { Investment in maintenance and development of the transpor- } \\
\text { tation network to the destination (maritime sector) }\end{array}$ \\
\hline$\%$ of new real estate developments intended for tourism & $\begin{array}{l}\text { GDP at basic price of the cultural industry, services related to } \\
\text { the arts, entertainment and recreation, and accommodations } \\
\text { and restaurant services }\end{array}$ & $\begin{array}{l}\text { GDP at basic price of the cultural industry, services related to } \\
\text { the arts, entertainment and recreation, and accommodations } \\
\text { and restaurant services }\end{array}$ \\
\hline $\begin{array}{l}\text { Number (percentage) of companies with an } \\
\text { eco-responsible label }\end{array}$ & $\begin{array}{l}\text { Number of companies that have acquired } \\
\text { the «Qualité Tourisme Gaspésie» label }\end{array}$ & $\begin{array}{l}\text { Number of companies that have acquired } \\
\text { an environmental label }\end{array}$ \\
\hline$\%$ of income generated by tourism in the community & Tourist spending & Tourist spending \\
\hline$\%$ of tourism jobs held by local residents & Number of jobs generated by tourism industry & Number of jobs generated by tourism industry \\
\hline$\%$ of return visits & $\begin{array}{l}\text { Average occupancy rate of accommodations including } \\
\text { campsites }\end{array}$ & $\begin{array}{l}\text { Average occupancy rate of accommodations including } \\
\text { campsites }\end{array}$ \\
\hline Number of visits to heritage and cultural sites & Number of visitors to the region's three national parks & Number of visitors to the region's three national parks \\
\hline Volume of tourists & Volume of tourists & Volume of tourists \\
\hline
\end{tabular}


Figure 2 : STI selection criteria (source : authors' compilation).

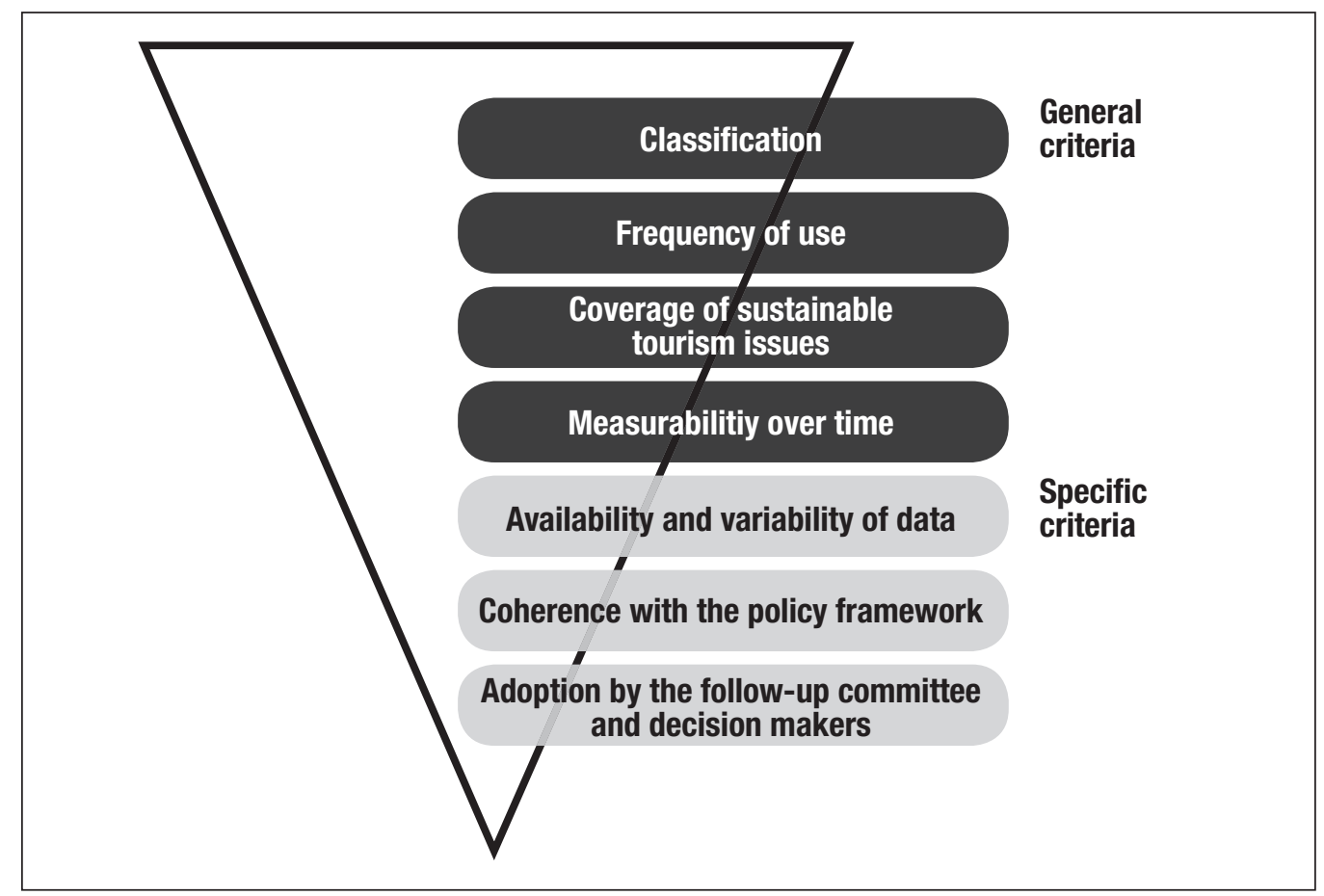

\section{Results and discussion}

By applying the seven criteria specified above to the initial comprehensive list, we produced a list of 20 STI. The first four criteria served to reduce the list of 507 indicators to the most widely used and best documented ones, at an optimal number that would systematically cover the main dimensions of sustainable development. The three specific criteria let us adapt the grid of 20 indicators to the context of each tourism region to ensure consistency with their policy framework. The correspondence between the indicators is presented in Table 5, from which we make three main observations.

First, most of the STI adopted by the two regions differ from the 20 STI resulting from the application of the general criteria. The data availability constraints often necessitated the use of "substitute" indicators. This observation underlines the precariousness of the availability of statistical data related to sustainable tourism, and enables us to target indicators about which the regions should provide more information.

Second, the STI did not vary considerably between regions. Presumably, the strategy adopted minimized the use of overly specific indicators and thus attenuated the risk of measuring mainly the dimensions on which the region is performing well.

Third, both regions retained indicators for which data are scant or even nonexistent. These decisions were made by the regional authorities with a view to gradually filling the information gaps as part of a follow-up of their sustainable tourism policy framework. These data notably concern the use of public transport (highway and maritime networks), degree of satisfaction of the local population with tourism development, recycling rate, and energy consumption of the tourism sector. This process therefore underlined gaps in current statistics pertaining to sustainable tourism at Québec destinations. It prompts various levels of government working in the tourism sector to gather important information required for assessment of tourism in a sustainable development perspective.

\section{Conclusion}

This paper presented the strategy adopted by the tourism regions of the Gaspésie and the Îles de la Madeleine to select a series of sustainable tourism indicators that could support their policy frameworks. The formulation of the guiding principles of their tourism policy has favoured active participation by all stakeholders. In contrast, the formulation of indicators allowing the follow-up and assessment of the objectives of this policy initiative was conferred on external experts, who were assigned to choose recognized pertinent indicators and ensure sufficient coverage of the dimensions of sustainable tourism, to avoid adoption of an overly specific "made-to-measure" indicator grid.

Methodologically, this contribution describes the search for a compromise between a scientific basis that rests on recognized experience, and a comprehensive base to guarantee awareness. The indicator grid resulting from the selection strategy proposed was submitted to the regional authorities for approval, to ensure its coherence with the policy frameworks and that the indicators are measurable and usable.

The strategy adopted by the Gaspésie and the Îles de la Madeleine is an example that illustrates the sound integration of scientific expertise and local experience. 
It demonstrates that a participating approach can be enhanced by an external scientific contribution, particularly to guarantee the validity and credibility of indicators used to assess the attainment of objectives of the policy framework. Such a strategy can also be applied to other destinations owing to its flexibility.

\section{References}

BELL, Simon and Stephen MORSE (2008) Sustainability Indicators:

Measuring the Immeasurable? London: Earthscan, 2nd edition, 228 p.

BOULANGER, Paul-Marie (2004) Les indicateurs du développement durable: un défi scientifique, un enjeu démocratique. Les séminaires de l'Iddri, no $12,24 \mathrm{p}$.

BUTLER, Richard (1999) "Sustainable tourism: A State-of-the-Art Review”, Tourism Geographies, Vol. 1, n 1, p. 7-25.

CHOI, Hwan Suk and Erkan SIRAKAYA (2006) "Sustainability Indicators for Managing Community Tourism”, Tourism Management, vol. 27, $\mathrm{n}^{\circ}$ 6, p. 1274-1289.

CRÉGÎM - Conférence régionale des élus Gaspésie-Îles-de-la-Madeleine (2010) Pour un tourisme durable en Gaspésie. PCDTG. Gaspésie: CRÉGÎM, November, $30 \mathrm{p}$.

EUROPEAN ENVIRONMENT AGENCY (2001) Environmental Benchmarking for Local Authorities: From concept to practice. Copenhagen: Environmental Issue Report, no 20, 64 p.

GAHIN, Randa; Vesela VELEVA and Maureen HART (2003) "Do Indicators Help Create Sustainable Communities?”, Local Environment, vol. 8, $\mathrm{n}^{\circ}$ 6, p. 661-666.

HICKEY, Gordon M. and John L. INNES (2008) "Indicators for Demonstrating Sustainable Forestry Management in British Columbia, Canada: An International Review", Ecological Indicators, vol. $8, n^{\circ} 2$, p. 131-140.

HOLMAN, Nancy (2009) "Incorporating Local Sustainability Indicators into Structures of Local Governance: a Review of the Literature". Local Environment, vol. 14, $\mathrm{n}^{\circ}$ 4, p. 365-375.

HUNTER, Colin (1997) "Sustainable Tourism as an Adaptive Paradigm", Annals of Tourism Research, vol. 24, $\mathrm{n}^{\circ}$ 4, p. 850-867.

MASCARENHAS, André; Pedro COELHO; Eduarda SUBTIL and Tomas B. RAMOS (2010) "The Role of Common Local Indicators in Regional Sustainability Assessment”, Ecological indicators, no 10, p. 646-656.

MILLER, Graham (2001) “The Development of Indicators for Sustainable Tourism: Results of a Delphi Survey of Tourism Researchers", Tourism Management, vol. 22, nº 4, p. 351-362.

MITCHEL, Gordon (1996) "Problems and Fundamentals of Sustainable Development Indicators", Sustainable Development, no 4, p.1-11.
Municipalité des Îles-de-la-Madeleine (2006) Politique-cadre de développement touristique. Îles de la Madeleine: Municipalité des Îles-de-la-Madeleine, <http://www.tourismeilesdelamadeleine.com/ FichiersUpload/Documents/web-20100930153050politique-cadrede-developpement-touristique-de-la-municipalite-des-iles-de-lamadeleine.pdf $>$, retrieved on May 27, 2011.

National Geographic Traveler (2010) “Places Rated”, National Geographic Traveler, published in November/December 2009, <http://traveler. nationalgeographic.com/2009/11/destinations-rated/list-text>, retrieved on May 27, 2011.

NIEMEIJER, David and Rodolf S. DE GROOT (2008) "A Conceptual Framework for Selecting Environmental Indicators Sets", Ecological Indicators, vol.8, $\mathrm{n}^{\circ} 1, \mathrm{p} .14-25$.

RAJAONSON, Juste and Georges A. TANGUAY (2010) "Le développement durable au Québec: classement des 25 plus grandes villes", Canadian Journal of Urban Research/Journal canadien de recherches urbaines, vol. 18, n 2, p. 40-77.

RAMETSTEINER, Ewald; Helga PÜLZL; Johanna ALKAN-OLSSON and Pia FREDERIKSEN (2011) "Sustainability Indicator Development: Science or Political Negotiation?", Ecological Indicators, vol.11, $\mathrm{n}^{\circ} 1$, p. 61-70.

REED, Mark S.; Evan D.G. FRASER and Andrew J. DOUGILL (2006) "An Adaptive Learning Process for Developing and Applying Sustainability Indicators with Local Communities", Ecological Economics, vol. 59, n 4, p. 406-418.

SHIELD, Deborah J.; Slavko V. SOLAR; Wade E. MARTIN (2002) "The Role of Values and Objectives in Communication Indicators of Sustainability", Ecological Indicators, vol. 2, n 1-2, p. 146-160.

STABLER, Mike J. (1997) Tourism and Sustainability: Principles to Practice, Wallingford: CABI International. $404 \mathrm{p}$.

TANGUAY, A. Georges; Juste RAJAONSON; Jean-François LEFEBVRE and Paul LANOIE (2009) "Measuring the Sustainability of Cities: An Analysis of the Use of Local Indicators", Ecological Indicators, vol. 10, $n^{\circ} 2$, p. 407-418.

TASSER, Erich; Elizabeth STERNBACH and Ulrike TAPPEINER (2008) "Biodiversity Indicators for Sustainability Monitoring at Municipality Level: An Example of Implementation in an Alpine Region", Ecological Indicators, vol. 8, $\mathrm{n}^{\circ}$ 3, p. 204-223.

WONG, Cecilia (2006) Indicators for Urban and Regional Planning. New York: Routledge. 217 p.

World Tourism Organization [WTO] (2004) Indicators of Sustainable Development for Tourism Destinations: A guidebook, Madrid: UN-WTO. 514 p. 